\title{
ARABIC MATERIAL DEVELOPMENT DESIGN FOR SENIOR HIGH SCHOOL
}

\author{
Shafruddin Tajuddin, Muhammad Kamal, Zuryati \\ Universitas Negeri Jakarta, Indonesia \\ Jl. Rawamangun Muka, Rawamangun, Pulo Gadung, Jakarta, 13220, Indonesia \\ Corresponding E-mail: shafruddin.ta@unj.ac.id
}

\begin{abstract}
The aims of the research were to develop Arabic learning material model for the senior high school level which was able to become a standard textbook in Arabic learning for high school. It was a realization of the National Language Politics policy that stated, Arabic as a language of religion and culture is taught from elementary school to university level. The research used to research and development $(\mathrm{R} \& \mathrm{D})$ approach that refers to Borg and Gall theory. There are 10 steps in the development research cycle. However, it was given the small-scale research, which developed materials and media Arabic learning in Jakarta area, this research did at the stage of getting the final product, namely the prototype of Arabic learning material developed. The research was begun through survey research to obtain an empirical sequence of Arabic learning as a basis to support rational empirical strategies in the development design of Arabic learning materials in high school. This research produced Arabic learning textbooks of class X to class XII at the High School level which are equipped with media.
\end{abstract}

Keywords: $\quad$ Arabic Language Skills, Arabic Learning, Materials, Textbook

\section{Introduction}

The public has given the attention-getting bigger to Arabic development, some of the indicators that Arabic has studied starting from the elementary school level, junior high school, high school to university. This is a realization of the National Language Politics.

Education is the interactions between teachers and students to achieve educational goals. Teachers, students, and educational goals are the main components of education. Educating is professional work, therefore teachers as the main actors of education are professional educators. ${ }^{1}$ Arabic language education is the process of cultivating knowledge and skills in Arabic to realize all the potential of people's Arabic

${ }^{1}$ Nana Syaodih Sukmadinata, Pengembangan Kurikulum, Teori dan Praktek, (Bandung: Penerbit PT Remaja Rosdakarya, 1997), 191. 
ability. While the educational institution is a mode used to carry out the process of language education earlier.

The Arabic language education institution that carries out Arabic learning have a purpose and these objectives are various. Some aim is to develop the Arabic communication ability in accordance with the situation, functions and topics of language use, others are aimed to develop the analysis of source knowledgeability through Arabic references.

The Arabic language education institution is a language education system that prepares students to use their Arabic language ability in society. Because the essence of each language education is how the knowledge and language skills possessed, a graduate of the education program can use it in accordance with the demands of the community.

Arabic learning at the state high school level has not been evenly distributed in all schools and has not developed in the direction of actual Arabic language skills. The secondary, senior high school education curriculum stated that Arabic language lessons have not yet gained a maximum position and in some high schools are only inserted in religious studies, although there are also those which have become independent subjects, but these are not optimal in teaching, and do not know what qualifications are desired the learning outcomes.

Whereas in high school that are characterized by Islam, such as Madrasah Aliyah (MA), Arabic learning is indeed distinguished from religious studies. However, the learning of Arabic in the $M A$ has not been maximized to get the ability what is desired from the learning outcomes, and in the teaching process, it is also more giving the rules of the Arabic language which can actually make it difficult for them to learn. In addition, the giving of Arabic rules is not systematically planned based on the focus to be achieved on students' Arabic language skills.

This is due to the fact that there is no planned Arabic language education system and effective, and sustainable Arabic language learning methods at the high school level. This is the need for appropriate planning of Arabic learning strategies at the high school level.

Arabic learning strategies planning in high school is very necessary because the strategy is a good plan to manage the implementation of the language teaching and learning process that we will carry out to achieve specific goals. To formulate an appropriate strategy in Arabic learning at the high school level, research is needed in that field. The research is expected to produce an Arabic language learning material model in high school that can be used as a standard system, both at the State High School and the Islamic Senior High School.

Based on this background, the formulation of the problem is: "How is to develop Arabic language learning material at the high school/Islamic high school level to improve students' Arabic language skills?"

The aims of the study are to formulate a strategy that is accurate and appropriate in the Arabic learning process at the Senior High School or Islamic Senior 
High School level and the development of material and learning media. Therefore, this research was carried out with the main aim of developing Arabic language learning material at the Senior High School or Islamic Senior High School level. This objective is elaborated as follows: (1) Producing Arabic textbooks designed according to the needs' analysis of teachers and students who refer to Competency Standards (Core Competencies, and Basic Competencies). (2) Creating a new material model in Arabic learning at the Senior High School or Islamic Senior High School level, because in this model, Arabic language teaching materials are designed with language material that is suitable for the users of this textbook, in addition, it is also equipped with interactive learning media.

The importance of this research is aimed at obtaining products whose results are expected to have a large contribution to make Arabic language learning strategies and learning materials and devices for Senior High School or Islamic Senior High School level and the qualifications is expected from high school graduates in Arabic learning. To achieve of that purposes, the teacher has to make the needs analysis. Aladdin concluded that teachers, syllabus and course designers have to put efforts to design and develop attractive and innovative course materials. It should focus on an interesting and stimulating materials and contents together with an attractive layout and design to cultivate motivation among the learners of Arabic language. ${ }^{2}$

This research becomes important and provides benefits because of several things, among others: First, the development of Arabic language learning materials using interactive learning media which are produced a textbook (classes X, XI, and XII) which has completed interactive media and are expected to improve the quality of Arabic learning with indicators, i.e. students become more interested in Arabic learning and students' Arabic language skills achieved increase. Second, if the students have the habit to use Arabic textbooks with interactive media, students are expected to be able to use Arabic better, so that they have strong personal competencies. Third, the Senior High School or Islamic Senior High School can produce graduates who have strong language competencies and personal competencies as mentioned previously.

This will improve the quality of education and make secondary education still exist and the students are able to compete with other secondary education. Meanwhile, the government as the state organizing institution, in this case, the Ministry of National Education and Ministry of Religion which has the Senior High School or Islamic Senior High School that are capable of organizing quality education system, it will increase their dignity in the international community.

The textbook produced in this study is a new model for Arabic learning at the High School or Islamic High School level, because, in this model, Arabic language learning material includes four language skills, enriching vocabulary with crossword

2 A. Aladdin, "A Needs Analysis for the Course Materials Design of the Arabic Language Course", International Journal of Social Science and Humanity, Vol. 6, 2016, https://doi.org/10.7763/IJSSH.2016.V6.684 
puzzle games, and equipped with interactive media which is, of course, the learning model is different from before. It is effective to support Arabic learning. Because some research has evidence it. Online games approach is recommended as a tool that can enhance students' ability to master the Arabic language. Appropriate models need to be produced as effective learning materials especially in the design and development of online Arabic language games. This concept paper explores elements of development and digital game-based learning model in the process of building Arabic language online games at school. This study describes the design elements as the results of the Arabic language online games development. The implications of this study can serve as a guideline for the development and effectiveness of future learning of Arabic language through online games at school. ${ }^{3}$

Different finding research shown that in the field of Arabic language learning emphasize constructing learning opportunity environments, it is important which contents are included and it is also students' great interest how these contents are presented. Lecturers and instructors tried to provide instructional explanations. Furthermore, they communicate and demonstrate prior knowledge and student motivation in determining learning outcomes. The learning provides student opportunity to acquire conceptual knowledge and language competency. The article concludes by considering how embodied language material learning to religious content is the way to speed up two subject in one teaching for curriculum enhancement. ${ }^{4}$

\section{Method}

The research used mixed research with research and development (R\&D) method. The research and development is a process to use to develop and validate educational products, such as syllabus, learning materials, textbooks, learning methods, and others that are carried out in a cycle of research and development. The procedure of research used the Borg and Gall concept. There are 10 steps in this development research cycle. ${ }^{5}$ The research is done in the Jakarta area, it is possible to limit the steps of research. This research only reached the stage of obtaining the final product, namely the material prototype and the Arabic learning media developed.

${ }^{3}$ M. Hamizul, \& N. M. Rahimi, "Design and Development of Arabic Online Games - A Conceptual Paper", Procedia - Social and Behavioral Sciences, 174, 2015, 1428-1433. https://doi.org/10.1016/J.SBSPRO.2015.01.771

${ }^{4}$ I. S. Wekke, "Arabic Learning Material of Higher Education Muslim Community North Sulawesi”, Dinamika Ilmu, Vol. 17, No. 2, 2017, 175-189. https://doi.org/10.21093/di.v17i2.863

5 Albinus Silalahi, "Development Research (Penelitian Pengembangan) dan Research \& Development (Penelitian dan Pengembangan) dalam Bidang Pendidikan/Pembelajaran", Seminar dan Workshop Penelitian Disertasi, 3 Februari 2017, Medan: Program Doktoral Pascasarjana Universitas Negeri Medan, 2017, 10-11. 
The development of Arabic material and learning media is designed by utilizing the results of the analysis of the needs of teachers and students, as well as analysis of documentation in existing Arabic learning materials.

In general, the object of research is to create Arabic language learning materials and media at High School level which are expected to be able to become the standard of teaching and learning processes at the high school level in order to improve students' Arabic skills.

The research consisted of two variables, namely Arabic language learning materials and students' Arabic learning media. Data collection research was conducted by conducting a survey of high schools that teach Arabic in the Jakarta area. This paper only describes the development of Arabic language learning material at the high school level and its equivalent in the form of an interactive media textbook and support for the textbook.

\section{Result and Discussion}

\section{Real Conditions of Arabic Language Teacher Background and Students in High School}

It is viewed from the aspect of official education, Arabic teachers at the high school / Islamic high school level do not all have Arabic education backgrounds, there are 6 schools from 14 schools whose teachers are officially educated from the Arabic study program, while other Arabic teachers are vary their official education. While the teacher's background in terms of his Arabic language skills, is quite varied, both through official education at the Islamic Junior High School, Islamic High School/Pesantren, and Strata-1 levels, as well as through Arabic language courses and training. Of course, one's educational background will bring out differences in the insights and knowledge that he mastered, for example, teachers who come from teacher education, insight and pedagogical knowledge are broader than teachers from non-teacher training. This is logical, because one learns it regularly, while the other does not learn it.

The different background will lead to different perspectives on Arabic learning. The teacher has language education backgrounds will position themselves as language teachers, not linguists. While the teacher does not have language education background will position themselves as linguists, not language teachers. If it is associated with the instructional goals to be achieved, the task of the language teacher is to strive, so that students become able to speak the language they learn. So, the teacher's job is to teach language and not teach language theory.

Pateda has cited Bell's opinion, stated that there is a difference between Language Teacher and Language Experts in terms of three (3) things: (1) Objectives, (2) Methods, (3) Attitudes. In terms of goals; linguists aim to explain the phenomenon of natural language, while language teachers guide students to learn the language. In terms of methods; linguists use abstract and formal methods, while language teachers use methods that are functional and practical. In terms of attitude; linguists behave that language is faced with systems, both form and meaning, while language teachers 
behave that the language faced is a set of skills. ${ }^{6}$ From this theory, it is known that some Arabic language teachers at the high school / Islamic high school level focus on learning are qawaid. In addition, others focus on language skills learning. Good language learning is comprehensive learning. This means that Arabic language learning must include both language skills and linguistic knowledge. Language competence will not run well without linguistic competence. Linguistics competence must be applied in its language competence, not just knowledge.

As the aspects of learners or students who studied Arabic at the high school or Islamic high school level, the majority of their backgrounds come from junior school, it is not from Islamic Junior High School. Data shows that high school students, both public and private, are mostly from junior school background. While Islamic High School students, both public and private, turned out to vary. Some of them have Islamic junior high school backgrounds, 50\% have Islamic junior high school backgrounds, 50\% have junior high school backgrounds, 65\% have Islamic junior high school, 35\% have junior high school backgrounds, $60 \%$ have Islamic junior high school backgrounds, $40 \%$ are junior high school backgrounds.

The real conditions of students rise different backgrounds in Arabic language skills, some even they don't know Arabic at all. This situation of students will cause difficulties for teachers in Arabic learning. Therefore, it is very necessary to have a book that pays attention to the condition of students like that, so that teachers can overcome Arabic learning to be easy by referring to the textbook.

If learners are students at the secondary school level, there are several principles that are in accordance with their character and psychology, including Learners will learn optimally if they are activated with the target language used in the communication process, both oral and written that is appropriate with their abilities, needs and interests. ${ }^{7}$ This principle requires the creation of a teaching and learning environment enriched with target language material, so the implications for the teacher are: (1) The teacher creates an atmosphere that encourages the behaviour and use of the target language, (2) The teacher tries to provide target languages display facilities, such as wall magazines, audio and video tapes.

\section{Textbooks and Arabic Learning Materials in High School}

Textbooks used in Arabic learning at the high school level is varied, these refer to the textbooks published by the Ministry of Religion, some books refer to textbooks issued by organizations that overshadow their educational institutions, some are based on students' workbook and do not adhere to a specific book. All books used are not equipped with learning media, while the media used in the learning comes from the improvisation of the teacher. As for the learning process, most of them are focused on

\footnotetext{
${ }^{6}$ Mansoer Pateda, Linguistik Terapan, (Yogyakarta: Penerbit Nusa Indah, 1991), 37.

7 Suwarna Pringgawidagda, Strategi Penguasaan Berbahasa, (Yogyakarta: Penerbit Adicita Karya Nusa, 2002), 28-29.
} 
what is in the book. While from the aspect of vocabulary learning, teachers give more memorization of vocabulary, both every day and every meeting with a varied process.

According to Tarigan ${ }^{8}$, quality textbooks have characteristics, including: (1) bases, principles and perspectives in the form of theories from psychology, language and so on; (2) relevant with the curriculum; (3) it is appropriate with learners' interests and characteristics; (4) stimulating learning activities as subjects of learning not objects; (5) illustrative. ${ }^{9}$ So, one of the characteristics of a good textbook is according to the interests and characteristics of the learner. It means that teaching material is the content is given to students during the learning process according to their level. Through these teaching materials, students are delivered to the learning objectives, namely completing the language learned.

Language books contain teaching materials that are arranged in a planned manner to improve the user's language skills. The nature of teaching material is the content is given to students during the learning process. Through the teaching material, students are delivered to the learning objectives. In other words, the learning objectives to be achieved are coloured and shaped by teaching material. Teaching material is the content of the subjects is given to students with the curriculum used. The teaching material can be in the form of facts, principles, and skills. ${ }^{10}$

The real condition of the Arabic textbook is not accompanied by media, even though learning media is a tool that is used as a channel to convey learning material to learners. One of the advantages of using media of learning is to increase learners' interest in learning, and good interest in learning will produce good quality. Besides that, learning is not monotonous so it is not boring. Therefore, departing from the benefits obtained in Arabic learning, it is necessary to have a textbook compiled along with the learning media, either in the form of language games or linguistic training.

The real condition of Arabic language learning material at the high school level refers to textbooks used in each school. Broadly, all teaching material revolves around linguistics material and language skills material, especially qawaid or Arabic grammar structures. In the learning process, most of the two materials are not balanced. Some are more focused on language skills and there are also more in qawaid learning. From the aspect of the content, the material is easy and there is also very high content. Specifically, language skills materials focus the learning is not emphasized on all four skills, but these focused on only one skill, two skills, or three skills. The real condition can be seen in the following table:

\footnotetext{
${ }^{8}$ Henry Guntur Tarigan, Pengajaran Kompetensi Bahasa, (Bandung: Penerbit Angkasa, 1990).

9 Suwarna Pringgawidagda, Strategi Penguasaan Berbahasa, 142-143.

${ }^{10}$ Nana Sudjana, Dasar-dasar Proses Belajar Mengajar, (Bandung: Penerbit Sinar Baru, 1989), 67.
} 
Ara6iyât Jurnal Pendidikan Bahasa Arab dan Kebahasaaraban, 6 (1), 2019

Table 1. The Real Condition of Arabic Learning Material for High School Level

\begin{tabular}{|c|c|c|c|}
\hline No & Material & $\begin{array}{l}\text { Focusing on } \\
\text { Language Skills } \\
\text { Emphasize }\end{array}$ & $\begin{array}{l}\text { Among Language Skills } \\
\text { and Linguistics }\end{array}$ \\
\hline 1 & $\begin{array}{l}\text { The level of books is easy and } \\
\text { more material is available to } \\
\text { connect letters }\end{array}$ & Kalam (speaking) & $\begin{array}{l}\text { It is more emphasis on } \\
\text { qawaid than language skills }\end{array}$ \\
\hline 2 & Very high, more Qawaid & Istima' and Kalam & $\begin{array}{l}\text { It Focuses on reciting } \\
\text { what has been learned }\end{array}$ \\
\hline 3 & $\begin{array}{l}\text { The material does not have } \\
\text { specific tools }\end{array}$ & Kalam, istima; qiraah & $\begin{array}{l}\text { Language skills are more } \\
\text { dominant }\end{array}$ \\
\hline 4 & $\begin{array}{l}\text { There is a dictionary behind the } \\
\text { book }\end{array}$ & $\begin{array}{l}\text { Reading and } \\
\text { speaking }\end{array}$ & $\begin{array}{l}\text { Qawaid does not need, } \\
\text { language skills are greater }\end{array}$ \\
\hline 5 & $\begin{array}{l}\text { Material level is very high. It is } \\
\text { suitable for students from Islamic } \\
\text { junior high school, but it is not } \\
\text { from junior high school. Mufrodat } \\
\text { is lacking. }\end{array}$ & Speaking, Reading & It is greater than qawaid \\
\hline 6 & $\begin{array}{l}\text { It Focuses on some scholars } \\
\text { (language skills). Lack of pictures }\end{array}$ & $\begin{array}{l}\text { Qiraah, kalam, and } \\
\text { istima' }\end{array}$ & $\begin{array}{l}\text { It is greater for language } \\
\text { skills, especially reading }\end{array}$ \\
\hline 7 & $\begin{array}{l}\text { Class } \mathrm{X} \text { is too long, class } \mathrm{XI} \text { and } \\
\mathrm{XII} \text { have no meaning }\end{array}$ & Reading, listening & $\begin{array}{l}\text { It focuses on language } \\
\text { skills }\end{array}$ \\
\hline 8 & It is greater to language learning & Writing & $\begin{array}{l}\text { It arranged and connected } \\
\text { the sentence }\end{array}$ \\
\hline 9 & $\begin{array}{l}\text { Qiraah material that is preceded } \\
\text { by vocabulary }\end{array}$ & Reading & There is a balance \\
\hline 10 & $\begin{array}{l}\text { It is not arranged, but it focuses } \\
\text { on the comprehension of Arabic } \\
\text { material }\end{array}$ & Reading, writing & There is a balance \\
\hline 11 & $\begin{array}{l}\text { The material does not lead to } \\
\text { deepening of religion }\end{array}$ & $\begin{array}{l}\text { Qiraah } \\
\text { (comprehension) }\end{array}$ & It focuses on qawaid \\
\hline 12 & $\begin{array}{l}\text { The material focused on the } \\
\text { questions issued by the } \\
\text { Muhammadiyah region. }\end{array}$ & Listening, speaking & $\begin{array}{l}\text { It is Unbalanced, it is } \\
\text { more emphasis on } \\
\text { listening and speaking }\end{array}$ \\
\hline 13 & $\begin{array}{l}\text { The material is concise but it } \\
\text { does not lead to understanding } \\
\text { religion }\end{array}$ & Qiraah & There is a balance \\
\hline 14 & $\begin{array}{l}\text { It is More memorization, } \\
\text { everyday material is easier to } \\
\text { understand }\end{array}$ & Listening, speaking & $\begin{array}{l}\text { It is Unbalanced, the } \\
\text { pressure is on listening } \\
\text { and speaking, while qawaid } \\
\text { is lacking }\end{array}$ \\
\hline
\end{tabular}


In language learning, textbooks must cover overall language material including two language skills goals. It means that teaching materials are comprehensive in order to synergize the material with the strategies of teaching so that the Arabic learning material is not stagnant and monotonous in one method. Therefore, effective learning requires a new paradigm in designing teaching materials and learning. ${ }^{11}$

The first target is language skills which include listening, speaking, reading and writing. The first goal does not need to be limited to one or two language skills. But, students should be given the opportunity to acquire all their language skills. Language skills can also be associated with the use of language components as intended in structural linguistics, that language component. It consists of language sounds, vocabulary, and grammar. Mastery of the components of language is considered to be part of language skills. Azies explained that language skills are (1) Grammatical Competence, namely knowledge that underlies our ability to produce and understand sentences in a language. (2) Communicative competencies, namely our ability to use language for social and communicative interactions. (3) Language Proficiency. ${ }^{12}$ Meanwhile, Chomsky has made a fundamental difference between "one's knowledge of the rules of a language" and "the actual use of the language in real situations". ${ }^{13}$

In language learning, the scope of the overall language material includes two goals of language skills. The first target is language skills which include listening, speaking, reading and writing. The second target is the language component which consists of language sounds, vocabulary, and grammar. It must be understood that Arabic learning is at the high school/Islamic High School level is not studying the Arabic field. This means that students are not just learning Arabic grammar rules. However, these rules can be applied to language skills.

Therefore, the background of students from junior high school becomes a consideration factor in making teaching materials that are appropriate to their level. This can be dealt with by arranging and compiling language material in a simple and gradual manner so that the material of this language can be easily absorbed, and students have the ability to speak or use language which is supported by knowing about language structure theory.

\section{The Real Condition of the Material Aspects (Qawaid) in Class X Textbooks}

Data shows that linguistic material is focused on two material, namely sharf (morphology) and nabwu (syntax). Arabic learning begins with the introduction of morphology (words) which are arranged in various sentences. Even in textbooks " $A$ Lughah al-'Arabiyah al-Muyassarah for Class X at High School level" (02) and textbooks

11 Rihlatul Ilmiah, "Arabic Between The Challence of Extinction and The Prosfect of Development", Proceeding, International Seminar on Arabic Language, 22-24 Juli, Jakarta: Universitas AlAzhar Indonesia, 2010, Makalah Indonesia, 22-28.

12 Furqanul Azies dan A. Chaedar Alwasilah, "Pengajaran Bahasa Komunikatif, Teori dan Praktek", (Bandung: Penerbit PT Remaja Rosdakarya, 1996), 26-27

${ }^{13}$ Henry Guntur Tarigan, Pengajaran Kompetensi Bahasa, 22. 
Ara6iyât Jurnal Pendidikan Bahasa Arab dan Kebahasaaraban, 6 (1), 2019

"Arabic Language for Madrasah Aliyah Class X is the same level with high school" (04), all focused on morphological material. Meanwhile, the learning of syntactic material is presented in the fifth lesson in the textbook "Arabic Language and Literature Class X High School" (01) and in the second, third, and sixth lessons in the textbook "Arabic Class 10 for Madrasah Aliyab" (03). The real condition can be observed in the following table:

Table 1. Real Condition of Linguistic Materials for Class X at High School

\begin{tabular}{|c|c|c|c|c|c|c|c|c|}
\hline $\begin{array}{l}\text { Name of } \\
\text { Textbook }\end{array}$ & $\begin{array}{c}\text { Lesson } \\
1\end{array}$ & $\begin{array}{c}\text { Lesson } \\
2\end{array}$ & $\begin{array}{c}\text { Lesson } \\
3\end{array}$ & $\begin{array}{c}\text { Lesson } \\
4\end{array}$ & $\begin{array}{c}\text { Lesson } \\
5\end{array}$ & $\begin{array}{c}\text { Lesson } \\
6\end{array}$ & $\begin{array}{c}\text { Lesson } \\
7\end{array}$ & $\begin{array}{c}\text { Lesson } \\
8\end{array}$ \\
\hline 01 & تأنمائر - تذكير & - منصوب مائر & مفرد مثنى & الإشارة - مضام & - مجلة اسمية & فعل الأمر & ظرف & فعل النهي \\
\hline 02 & 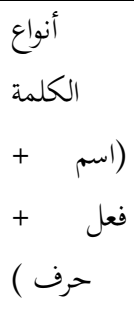 & علامة & أفسام & حروف & التصريف & مؤنث & والألفعال & \\
\hline 03 & معرفة نمكرة & والحمبر اسمية من & 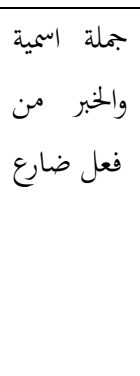 & مصدر - معاني & عندي ل معي & 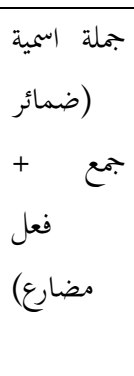 & & \\
\hline 04 & وقياسي ماعي & حرف الجر & حرف + على على & 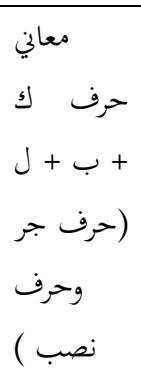 & & & & \\
\hline
\end{tabular}

01 : Arabic Language and Literature for Class X at High School

02 : Al-Lughah al-'Arabiyah al-Muyassarah for Class X at High School

03 : Arabic Language for Class X at Madrasah Aliyah (Ministry of Religion)

04 : Arabic Language Class X at Madrasah Aliyah relevant with High School 
Language material is not explained as a sequence, even it is very varied in its structure, even though the students who were targeted for Arabic learning with junior high school background whose notes during their studies in junior high school never studied Arabic because indeed Arabic was not contained in its curriculum. For example, book class X (01), the first lesson listed the main focus of learning is dhama'ir material (pronouns), tadækîr and ta'nits (masculine and feminism). However, the learning material is presented with a very varied sentence structure, such as the Islamic sentence, fi'liyah, the mudhare verb (present) and the madhi verb (past). The condition of language material like this, which is also available in other textbooks, will certainly be difficult to digest by students from junior school backgrounds.

This is what makes the stigma that Arabic learning is difficult. Because words, expressions, and sentences will not be maximally powerful if these are not arranged properly. Therefore, Arabic textbooks must be developed in arranging language material correctly or sentences so that they become well-composed, solid, steady and gradual sentences in length and structure in accordance with the level of students' language competence. The development of this language material can hold on to Chomsky's theory which says that language knowledge is the ability to make sentences. Therefore, language materials are arranged and compiled starting from the learning of simple sentences as sequence and continued to the development of simple sentences.

\section{Arabic Language Learning Materials Development for High School Level}

Based on the needs' analysis of Arabic learning at the high school level, textbooks need to be designed that help teachers and students to get effective Arabic learning process. Arabic textbook material development for grades 10 through 12 is produced by taking the current description of Arabic learning reality, and the results of Arabic learning needs identifying, the principles of Arabic learning and textbooks based on theoretical studies.

Arabic language learning at the high school level is designed by compiling Core Competencies (CC) and Basic Competencies (BC) and it is formulated for all levels, starting from grade 10 to grade 12 . Formulation of $\mathrm{CC}$ and $\mathrm{BC}$ includes language competence; listening, speaking, reading and writing, as well as the formulation of language competencies which include; grammatical enrichment (Arabic sentence structure) and vocabulary enrichment.

From the aspect of language material, textbooks are developed based on Chomsky's theory that language knowledge is the ability to make sentences. Therefore, the language material is arranged and compiled starting from simple sentences learning gradually, namely ismiyah sentences and filiyah sentences and it continued for developing simple sentences material, such as jar majrûr, mudhaf ilaih, and mausuf nature.

Textbooks for grade 10 contain 8 chapters, and language material is presented in stages and gradations, namely: ismiyah sentence in mudzakkar pattern, ismiyah sentence in muannats pattern, ismiyah and jar sentence, ismiyah and isim zharf sentence, 
ismiyah sentence and idhâfah phrase, fi'liyah with dhamir (أنت - أن (أن adjective, fi'liyah sentence with dhamir (هي -هو (هي (ن) -أنتم -أنت (ن) fi'liyah sentence with dhamir).

Textbooks for grade 11 contain 8 chapters, and language material is presented in stages and gradations, namely: ismiyah and filiyah sentences with fi'il mudhari manshub, fi'liyah sentences with three basic patterns, ismiyah sentences with taqdimul khabar, istifhamiyah sentences, fi'liyah sentence with fi'il mudhari majzum, fi'liyah sentence in negative pattern, ismiyah sentence in negative pattern, fi'liyah sentence with fi'il madhi.

Textbooks for grade 11 contain 8 chapters, and language material is presented in stages and gradations, namely: ismiyah sentence with (إنّإ), ismiyah sentence with (كان), fi'liyah/ismiyah sentence with fi'il madhi (هو), fi'liyah/ismiyah sentence with fi'il madhi (هي), ismiyah sentence with ( كان ( amr mudzakkar, fi'liyah sentence with $f i$ 'il amr muannats.

The textbook developed with language material designed and arranged as graduation and sequences, like as explaining previous. It is as a differentiator from existing textbooks, both written individually and as a team from an institution.

The themes of learning developed, adapted to the students' life and environment, as well as several Islamic leaders who are well known in society, especially is in Islamic history. The main themes of learning are presented in the form of dialogue and the grammatical concepts of Arabic Fuscha(standard), and these are presented in Arabic sentences simple in sequence from easy to difficult, from simple to complex, from concrete to abstract, from the closest environment too far environment that is from students' life.

In process of arranging material related with the Arabic culture. So, the student will get the soul of Arabic learning. Like as Wekke, research findings show that pesantren preserve traditional Arabic teaching and learning processes. They still carry out badongan (individual) and sorogan (classical). In addition to these performs they proceed other strategies and method to enhance students' language skill. There are seventeen practices that pesantren conducted. Those programs were linkage through 24 hours living environment line up. Finally, techniques. The culture that is apparent in pesantren provides meaning to the development of learning Arabic, especially in the environment for where it is developed. ${ }^{14}$ Therefore, this research provided the local concept that integrated with Arabic culture. It gave the positive impact. The teacher present the global material using local activity. Muharom Albantani \& Madkur shown that the integration of local wisdom is very essential and it could be executed by including the local wisdom values into the materials, allocated

${ }^{14}$ I. S. Wekke, "Arabic Teaching and Learning: A Model from Indonesian Muslim Minority," Procedia - Social and Behavioral Sciences, 191, 2015, 286-290, https://doi.org/10.1016/ J.SBSPRO.2015.04.2362 
time for discussion on local wisdom, classroom activities and the process of teaching linguistic skill. ${ }^{15}$

Theoretically, there are two steps of learning in trying to master the target language; (1) Acquisition, it means that the mastery of the target language (Arabic) unconsciously (implicitly), informally, or naturally. Mastery is done by habituating the use of the language in communication, (2) Learning, it means mastery of the target language (Arabic) is done consciously and formally. Stevick argues that the task of teachers includes three things: (1) developing communication competencies, (2) developing linguistic competencies, (3) developing personal competencies. ${ }^{16}$

This theoretical study is used in designing of Arabic language learning materials for the high school level: (a) Arabic textbooks, from grades 10 to 12, especially those are concerning language skills (listening, speaking, reading and writing), and enriching vocabulary that designed with the "Learning" approach. It means that students are taught consciously or explicitly to master all the skills and the Arabic vocabulary.

(b) Meanwhile, the use of Arabic sentence structures is designed with the "Acquisition" approach. This means that students gain the ability to use Arabic sentence structures (rules of speech) unconsciously (implicitly), namely by habituating the use of Arabic in their language skills, both listening, speaking, reading and writing. In other words, students are not taught "what is language", but are taught 'how to speak thoroughly'.

(c) The material used the structure of Arabic is presented in a coherent manner grade 10 to grade 12 , the learning material is explained by the ismiyah sentence structure and fi'liyah sentence with regard to gradation and continuity according to the level of ease and difficulty. The ismiyyah and filiyab sentences are presented in stages in accordance with the materials for the development of these two forms of Arabic sentences in gradual and continuous ways such as the use of fi'il mudhari, fi'il madhi, and fi'il amr.

(d) To obtain vocabulary mastery, students are taught using role play is Arabic learning card media. In addition, students were invited to play by guessing the vocabulary designed in the form of crossword puzzle where students were invited to be able to write from each Arabic letter.

15 A. Muharom Albantani \& A. Madkur, "Think Globally, Act Locally: The Strategy of Incorporating Local Wisdom in Foreign Language Teaching in Indonesia", International Journal of Applied Linguistics and English Literature, Vol. 7, No. 2, 2018, 1. https://doi.org/10.7575/aiac.ijalel.v.7n.2p.1

${ }^{16}$ Mansoer Pateda, Linguistik Terapan, 38. 
(e) Each textbook for grade 10 to 12, it is given the writing task in the form of dictation. This is as expected by the Arabic teacher at the school that students must be able to write Arabic correctly. In addition, the systematic presentation in each chapter is shown consistently, including competency standards to obtain religious values and affective values.

\section{Conclusion}

Based on the result of analysis can be summarized as follows: The Arabic learning material in a textbook for grades 10 to 12 high school has completed with the learning media, was developed by taking the description of the reality of Arabic learning, the results of identifying the needs of Arabic language teachers and students, and the principles of Arabic learning and textbooks based on theoretical studies.

Based on the needs of teachers and students, Arabic language learning material at the High School level is developed to improve students' Arabic language skills simultaneously, both language competence (listening, speaking, reading, and writing), and linguistics competencies that can be learned in stages and systematically in order to support increased language skills. Based on this need, there is a need for textbooks and media that support these capabilities.

Language competence is presented in an integral and coherent manner, as well as vocabulary material and enrichment of Arabic grammar, applied in these skills in accordance with the themes of the study. Language competence is presented in stages according to the level of ease and difficulty, and the material is presented in the sentence structures that are the subject of discussion. Students are accustomed to using the structure in their language skills. In other words, students are not taught "what is language", however, students are taught how to speak thoroughly.

The research result has a crucial suggestion for developing the quality of Arabic learning process. The Arabic language learning model at the High School level developed using Arabic learning interactive media, namely Hangman Arabic Flash Games and Game Cards, namely Arabic dominoes, card arranging sentences, cards combining images and words. The hangman game is expected to be developed with a variety of exercises, and also card games can be developed with a variety of language games.[]

\section{REFERENCES}

Aladdin, A. "A Needs Analysis for the Course Materials Design of the Arabic Language Course", International Journal of Social Science and Humanity, 2016 https://doi.org/10.7763/IJSSH.2016.V6.684

Azies, Furqanul., dan A. Chaedar Alwasilah. Pengajaran Bahasa Komunikatif, Teori dan Praktek, Bandung: Penerbit PT Remaja Rosdakarya, 1996. 
Ara6iyât Jurnal Pendidikan Bahasa Arab dan Kebahasaaraban, 6 (1), 2019

Hamizul, M., \& N. M. Rahimi. "Design and Development of Arabic Online Games A Conceptual Paper", Procedia - Social and Behavioral Sciences, 174, 2015, 14281433. https://doi.org/10.1016/J.SBSPRO.2015.01.771

Ilmiah, Rihlatul. "Arabic Between The Challence of Extinction and The Prosfect of Development", Proceeding, International Seminar on Arabic Language; 22-24 Juli, Jakarta: Universitas Al Azhar Indonesia, 2010.

Albantani, Azkia Muharom., \& Ahmad Madkur. “'Think Globally, Act Locally: The Strategy of Incorporating Local Wisdom in Foreign Language Teaching in Indonesia", International Journal of Applied Linguistics and English Literature, Vol. 7, No. 2, 2018, 1. https://doi.org/10.7575/aiac.ijalel.v.7n.2p.1

Pateda, Mansoer. Linguistik Terapan, Yogyakarta: Penerbit Nusa Indah, 1991.

Pringgawidagda, Suwarna. Strategi Penguasaan Berbahasa, Yogyakarta: Penerbit Adicita Karya Nusa, 2002.

Silalahi, Albinus. "Development Research (Penelitian Pengembangan) dan Research \& Development (Penelitian dan Pengembangan) dalam Bidang Pendidikan/Pembelajaran", Seminar dan Workshop Penelitian Disertasi, 3 Februari 2017, Medan: Program Doktoral Pascasarjana Universitas Negeri Medan, 2017.

Sudjana, Nana. Dasar-dasar Proses Belajar Mengajar, Bandung: Penerbit Sinar Baru, 1989.

Sukmadinata, Nana Syaodih. Pengembangan Kurikulum, Teori dan Praktek, Bandung: Penerbit PT Remaja Rosdakarya, 1997.

Tarigan, Henry Guntur. Pengajaran Kompetensi Bahasa. Bandung: Penerbit Angkasa, 1990.

Wekke, I. S. "Arabic Teaching and Learning: A Model from Indonesian Muslim Minority", Procedia - Social and Behavioral Sciences, 191, 2015, 286-290. https://doi.org/10.1016/J.SBSPRO.2015.04.236

Wekke, I. S. "Arabic Learning Material of Higher Education Muslim Community North Sulawesi", Dinamika Ilmu, Vol. 17, No. 2, 2017, 175-189. https://doi.org/10.21093/di.v17i2.863 